Article

\title{
Suppression of Food Allergic Symptoms by Raw Cow's Milk in Mice is Retained after Skimming but Abolished after Heating the Milk-A Promising Contribution of Alkaline Phosphatase
}

\author{
Suzanne Abbring ${ }^{1}{ }^{\circ}$, Joseph Thomas Ryan ${ }^{2}$, Mara A.P. Diks ${ }^{1}$, Gert Hols ${ }^{2}$, Johan Garssen ${ }^{1,2}$ and \\ Betty C.A.M. van Esch 1,2,*(D) \\ 1 Division of Pharmacology, Utrecht Institute for Pharmaceutical Sciences, Faculty of Science, Utrecht \\ University, 3584 CG Utrecht, The Netherlands \\ 2 Danone Nutricia Research, 3584 CT Utrecht, The Netherlands \\ * Correspondence: e.c.a.m.vanesch@uu.nl; Tel.: +31-625732735
}

Received: 19 April 2019; Accepted: 25 June 2019; Published: 30 June 2019

\begin{abstract}
Raw cow's milk was previously shown to suppress allergic symptoms in a murine model for food allergy. In the present study, we investigated the contribution of fat content and heat-sensitive milk components to this allergy-protective effect. In addition, we determined the potency of alkaline phosphatase (ALP), a heat-sensitive raw milk component, to affect the allergic response. $\mathrm{C} 3 \mathrm{H} / \mathrm{HeOuJ}$ mice were treated with raw milk, pasteurized milk, skimmed raw milk, pasteurized milk spiked with ALP, or phosphate-buffered saline for eight days prior to sensitization and challenge with ovalbumin (OVA). Effects of these milk types on the allergic response were subsequently assessed. Similar to raw milk, skimmed raw milk suppressed food allergic symptoms, demonstrated by a reduced acute allergic skin response and low levels of OVA-specific IgE and Th2-related cytokines. This protective effect was accompanied by an induction of $\mathrm{CD} 103^{+} \mathrm{CD} 11 \mathrm{~b}^{+}$dendritic cells and TGF- $\beta$-producing regulatory $\mathrm{T}$ cells in the mesenteric lymph nodes. Pasteurized milk was not protective but adding ALP restored the allergy-protective effect. Not the fat content, but the heat-sensitive components are responsible for the allergy-protective effects of raw cow's milk. Adding ALP to heat-treated milk might be an interesting alternative to raw cow's milk consumption, as spiking pasteurized milk with ALP restored the protective effects.
\end{abstract}

Keywords: alkaline phosphatase; allergic diseases; food allergy; immune regulation; milk processing; raw cow's milk

\section{Introduction}

Breastfeeding is the gold standard of infant nutrition. It is a complex matrix providing a unique combination of lipids, carbohydrates, proteins, vitamins and minerals. In addition, breast milk contains numerous components with immunomodulatory properties, such as immunoglobulins, lactoferrin, oligosaccharides, long-chain fatty acids, antioxidants and anti-inflammatory cytokines [1]. These bioactive components are potentially responsible for the allergy-protective effects associated with breastfeeding [2-4].

In analogy to breast milk, numerous epidemiological studies have shown that the consumption of raw, unprocessed, cow's milk can also reduce the risk of allergic diseases [5-9]. These epidemiological findings were recently confirmed by causal evidence, showing that raw cow's milk prevents the development of house dust mite-induced allergic asthma [10] and of OVA-induced food allergy [11] in murine animal models. However, due to the possible contamination with pathogens, raw cow's milk 
consumption is discouraged by regulatory authorities [12]. Even though risks from certified raw cow's milk, produced under strict hygienic and microbiological standards, are considered to be low [13], a zero-risk can never be attained. Cow's milk used for commercial purposes is therefore processed.

Milk processing, i.e., heat treatment and homogenization, ensures microbial safety and increases shelf life. Unfortunately, it also impacts the asthma- and allergy-protective effect of raw cow's milk $[5,10,14]$. Milk processing considerably alters raw cow's milk with most prominent effects on the fat content and heat-sensitive milk components. For both constituents, associations have been found in relation to the asthma- and allergy-protective effects. For the fat content of the milk, effects were mainly attributed to the levels of $n-3$ polyunsaturated fatty acids [14], whereas for the heat-sensitive milk components, the whey protein fraction was found to be associated with a reduced allergy risk [5]. Confirming that these raw milk constituents are indeed responsible for the observed allergy protection by showing causality is crucial. This knowledge will further support the development of mildly processed milk, or the addition of specific raw milk ingredients to heat-treated milk as an alternative to raw milk consumption.

In the current study, we investigated to which extent the fat content of the milk and the heat-sensitive milk components contribute to the allergy-protective effects of raw cow's milk by examining skimmed raw milk and pasteurized milk, respectively, in a murine ovalbumin (OVA)-induced food allergy model. In addition, we added alkaline phosphatase (ALP), one of the first bioactive raw milk components losing its activity upon heat treatment, to pasteurized milk to assess whether this restores the allergy-protective effect.

\section{Materials and Methods}

\subsection{Mice}

Three-week-old, specific pathogen-free, female $\mathrm{C} 3 \mathrm{H} / \mathrm{HeOuJ}$ mice, purchased from Charles River Laboratories (Sulzfeld, Germany) were housed in filter-topped makrolon cages (one cage/group, $n=6-8 /$ cage) at the animal facility of the Utrecht University (Utrecht, The Netherlands) on a $12 \mathrm{~h}$ light/dark cycle with unlimited access to food ("Rat and Mouse Breeder and Grower Expanded"; Special Diet Services, Witham, UK) and water. Upon arrival, mice were randomly allocated to the control and experimental groups and were habituated to the laboratory conditions for one week prior to the start of the study. Animal procedures were approved by the Ethical Committee for Animal Research of the Utrecht University and conducted according to the European Directive 2010/63/EU on the protection of animals used for scientific purposes (AVD108002015346).

\subsection{Milk Types}

Raw cow's milk was collected from a dairy farm (Macroom, Ireland). After collection, the raw cow's milk was divided into three aliquots. Aliquot 1 was stored without any treatment at $-20^{\circ} \mathrm{C}$ until further use (raw milk). Aliquot 2 was heated for $15 \mathrm{~s}$ at $78{ }^{\circ} \mathrm{C}$, cooled to $4{ }^{\circ} \mathrm{C}$ and then stored at $-20{ }^{\circ} \mathrm{C}$ until further use (pasteurized milk). Aliquot 3 was skimmed at $55{ }^{\circ} \mathrm{C}$ to remove the milk fat, cooled to $4{ }^{\circ} \mathrm{C}$ and stored at $-20^{\circ} \mathrm{C}$ until further use (skimmed milk; $0.1 \%$ fat). All milk types were produced for experimental purposes only (Danone Nutricia Research, Utrecht, The Netherlands). On the days of milk treatment (Experimental Days -9 to -2; Figure 1), milks were thawed at room temperature and part of the pasteurized milk was spiked with bovine intestinal ALP (pasteurized milk + ALP; 3 units/0.5 mL pasteurized milk; $10 \times$ higher concentration than present in raw cow's milk). ALP was kindly provided by Prof. Dr. W. Seinen (Utrecht University, Utrecht, The Netherlands). 


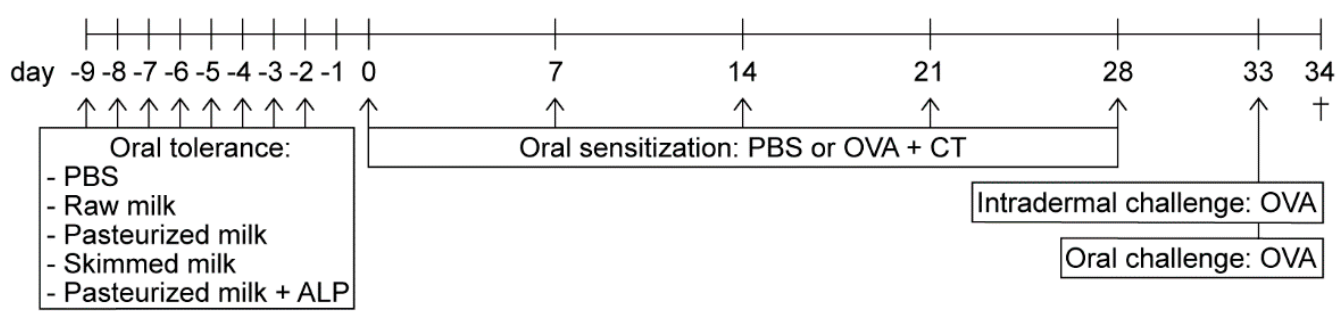

\begin{tabular}{lllll}
\hline Group & $\boldsymbol{n}$ & Tolerance & Sensitization & Challenge \\
\hline PBS & 6 & PBS & PBS + CT & OVA \\
OVA & 8 & PBS & OVA + CT & OVA \\
Raw milk & 8 & Raw milk & OVA + CT & OVA \\
Pasteurized milk & 8 & Pasteurized milk & OVA + CT & OVA \\
Skimmed milk & 8 & Skimmed milk & OVA + CT & OVA \\
Pasteurized milk + ALP & 8 & Pasteurized milk + ALP & OVA + CT & OVA \\
\hline
\end{tabular}

Figure 1. Schematic overview of the experimental setup. Female $\mathrm{C} 3 \mathrm{H} / \mathrm{HeOuJ}$ mice were randomly allocated to the control and experimental groups: PBS group (PBS-sensitized control mice; $n=6$ ), OVA group (OVA-sensitized allergic mice; $n=8$ ), raw milk group (raw milk-treated mice; $n=8$ ), pasteurized milk group (pasteurized milk-treated mice; $n=8$ ), skimmed milk group (skimmed milk-treated mice; $n=8$ ) and pasteurized milk + ALP group (pasteurized milk + ALP-treated mice; $n=8$ ). Mice were orally treated with $0.5 \mathrm{~mL}$ raw milk, pasteurized milk, skimmed milk, pasteurized milk spiked with ALP, or PBS (as a control). Following this oral tolerance induction period, mice were orally sensitized to OVA (20 mg/0.5 mL PBS) with CT as an adjuvant (10 $\mu \mathrm{g} / 0.5 \mathrm{~mL}$ PBS). PBS-sensitized control mice (PBS group) received CT alone. Subsequently, all mice were intradermally and orally challenged with OVA. Mice were killed on day 34 (as indicated by + ). PBS, phosphate-buffered saline; ALP, alkaline phosphatase; OVA, ovalbumin; $\mathrm{CT}$, cholera toxin.

\subsection{Animal Procedures}

A schematic representation of the experimental design is shown in Figure 1. On Experimental Days $0,7,14,21$ and 28 , mice ( $n=8$ /group) were orally sensitized to $20 \mathrm{mg}$ of the hen's egg protein OVA (grade V; Sigma-Aldrich, Zwijndrecht, The Netherlands) dissolved in $0.5 \mathrm{~mL}$ phosphate-buffered saline (PBS) containing $10 \mu \mathrm{g}$ cholera toxin (CT; List Biological Laboratories, Campbell, CA, USA) as an adjuvant. The PBS-sensitized control mice $(n=6)$ received CT alone $(10 \mu \mathrm{g} / 0.5 \mathrm{~mL}$ PBS). Prior to sensitization, mice were orally treated by using a blunt needle with $0.5 \mathrm{~mL}$ raw milk, pasteurized milk, skimmed raw milk, pasteurized milk spiked with ALP, or PBS (as a control) for eight consecutive days (Days -9 to -2). On Day 27, one day before the last sensitization, a blood sample was drawn via cheek puncture to measure basophil activation. On Day 33, five days after the last sensitization, all mice were challenged intradermally in both ears with OVA $(10 \mu \mathrm{g} / 20 \mu \mathrm{L}$ PBS $)$ to determine the acute allergic skin response. On the same day, mice were challenged orally with $50 \mathrm{mg}$ OVA dissolved in $0.5 \mathrm{~mL}$ PBS. Sixteen hours after the oral challenge (Day 34), a blood sample was taken, and mice were killed by cervical dislocation.

\subsection{Evaluation of the Acute Allergic Skin Response}

To assess the magnitude of the acute allergic skin response to OVA, mice were intradermally challenged in the ear pinnae of both ears with $10 \mu \mathrm{g}$ OVA in $20 \mu \mathrm{L}$ PBS. Ear thickness was measured in duplicate for each ear prior to and $1 \mathrm{~h}$ after the intradermal challenge using a digital micrometer (Mitutoyo, Veenendaal, The Netherlands). By subtracting the mean basal ear thickness from the mean ear thickness measured $1 \mathrm{~h}$ after the intradermal challenge, the ear swelling (expressed as $\Delta \mu \mathrm{m}$ ) was calculated. Isoflurane (Abbott, Breda, The Netherlands) was used for inhalation anesthesia to perform the intradermal challenge as well as the ear measurements. Measurements were performed blinded. 


\subsection{Basophil Activation Test}

The basophil activation test was performed as described previously [15], with few alterations. Briefly, whole blood was drawn from each mouse via cheek puncture on experimental Day 27 (one day before the last sensitization). Blood samples from two mice were pooled and incubated with RPMI 1640 medium (Lonza, Verviers, Belgium), anti-mouse IgE (0.125 $\mu \mathrm{g} / \mathrm{mL}$; eBioscience, Breda, The Netherlands) or OVA (20 $\mathrm{g} / \mathrm{mL}$; Sigma-Aldrich) for $90 \mathrm{~min}$ at $37^{\circ} \mathrm{C}$. Activation was stopped with PBS containing $5 \mathrm{mM}$ EDTA (Thermo Fisher Scientific, Paisley, Scotland). After washing the cells twice with PBS, red blood cells were lysed and fixed using a whole blood lysing reagent kit (Beckman Coulter, Brea, CA, USA) according to the manufacturer's instructions. Cells were then washed again, and non-specific binding sites were blocked by incubating cells for $15 \mathrm{~min}$ on ice with anti-mouse CD16/CD32 (Mouse BD Fc Block; BD Biosciences, Alphen aan de Rijn, The Netherlands). Cells were subsequently stained for $30 \mathrm{~min}$ on ice with CD4-PE and CD45R/B220-PE to gate out T cells and B cells and with IgE-FITC and CD49b-APC to select basophils. CD200R-PerCP-eFluor ${ }^{\circledR} 710$ was used as a marker for basophil activation. All antibodies were purchased from eBioscience. Flow cytometry was performed using FACS Canto II (BD Biosciences) and the results were analyzed using FlowLogic Software (Inivai Technologies, Mentone, Australia). Cut-off gates for positivity were established using the fluorescence-minus-one technique.

\subsection{Measurement of OVA-Specific Immunoglobulins in Serum}

Blood samples collected prior to sacrifice were centrifuged at 10,000 rpm for $10 \mathrm{~min}$ and serum was stored at $-20^{\circ} \mathrm{C}$ until analysis of OVA-specific immunoglobulins by means of ELISA. OVA-specific IgE levels were quantified as described previously [16], with few modifications. Briefly, high binding Costar 9018 plates (Corning Inc., New York, NY, USA) were coated overnight at $4{ }^{\circ} \mathrm{C}$ with $2 \mu \mathrm{g} / \mathrm{mL}$ purified rat anti-mouse IgE (BD Biosciences) in carbonate/bicarbonate buffer (0.05 M, pH 9.6; Sigma-Aldrich). The next day, plates were washed, blocked for $1 \mathrm{~h}$ with PBS/1\% bovine serum albumin (BSA; Sigma-Aldrich) and incubated for $2 \mathrm{~h}$ with serum samples at room temperature. After washing, plates were incubated for $1 \mathrm{~h}$ with $1 \mu \mathrm{g} / \mathrm{mL}$ OVA coupled to digoxigenin (DIG). Plates were then washed again, followed by $1 \mathrm{~h}$ incubation with $300 \mathrm{mU} / \mathrm{mL}$ anti-DIG-POD Fab fragments conjugated to horseradish peroxidase (Sigma-Aldrich). After washing again, the reaction was developed using $o$-phenylenediamine (Sigma-Aldrich) and stopped by $4 \mathrm{M} \mathrm{H}_{2} \mathrm{SO}_{4}$. The absorbance was measured at $490 \mathrm{~nm}$ using a Benchmark microplate reader (Bio-Rad, Veenendaal, The Netherlands). OVA-specific IgE levels are expressed in arbitrary units, calculated based on a titration curve of pooled sera serving as an internal standard. For OVA-specific IgG1 and IgA, high binding Costar 9018 plates were coated with $20 \mu \mathrm{g} / \mathrm{mL}$ OVA (Sigma-Aldrich) in carbonate/bicarbonate buffer and incubated overnight at $4{ }^{\circ} \mathrm{C}$. After overnight incubation, plates were washed and blocked for $1 \mathrm{~h}$ with PBS/1\%BSA. Serum samples were then incubated for $2 \mathrm{~h}$ at room temperature and after washing, plates were incubated for $1.5 \mathrm{~h}$ with biotinylated rat anti-mouse IgG1 or IgA detection antibody ( $1 \mu \mathrm{g} / \mathrm{mL}$; BD Biosciences). Plates were subsequently washed, incubated for $45 \mathrm{~min}$ with streptavidin-horseradish peroxidase $(0.5 \mu \mathrm{g} / \mathrm{mL}$; Sanquin), washed again and developed as described above for IgE. OVA-specific IgG1 and IgA levels are expressed as OD values.

\subsection{Spleen, Mesenteric Lymph Nodes (MLN) and Lamina Propria (LP) Cell Isolation}

Spleen and MLN single cell suspensions were obtained by crushing tissues through a $70 \mu \mathrm{m}$ nylon cell strainer using a syringe. Splenocyte suspensions were incubated with lysis buffer (8.3 $\mathrm{g}$ $\mathrm{NH}_{4} \mathrm{Cl}, 1 \mathrm{~g} \mathrm{KHC}_{3} \mathrm{O}$ and $37.2 \mathrm{mg}$ EDTA dissolved in $1 \mathrm{~L}$ demi water, filter sterilized) to remove red blood cells. Cell suspensions were resuspended in RPMI 1640 medium (Lonza), supplemented with 10\% heat-inactivated fetal bovine serum (FBS; Bodinco, Alkmaar, The Netherlands), penicillin (100 U/mL)/streptomycin (100 $\mu \mathrm{g} / \mathrm{mL}$; Sigma-Aldrich) and $\beta$-mercaptoethanol (20 $\mu \mathrm{M}$; Thermo Fisher Scientific) prior to ex vivo OVA-specific restimulation assays or in PBS/1\% BSA (Sigma-Aldrich) prior to 
cell stainings for flow cytometric analysis. For the isolation of small intestinal LP cells ( $n=6 /$ group), the small intestine was removed, cleared from fat and Peyer's patches, opened longitudinally, washed in PBS, and cut into $0.5 \mathrm{~cm}$ pieces. To remove epithelial cells and intraepithelial lymphocytes, these pieces were washed using Hank's Balanced Salt Solution (HBSS; Thermo Fisher Scientific) containing $15 \mathrm{mM}$ HEPES (Thermo Fisher Scientific), pH 7.2, and incubated $4 \times 15 \mathrm{~min}$ at $37^{\circ} \mathrm{C}$ with HBSS/HEPES buffer supplemented with $5 \mathrm{mM}$ EDTA, 10\% FBS and penicillin $(100 \mathrm{U} / \mathrm{mL}) /$ streptomycin $(100 \mu \mathrm{g} / \mathrm{mL}), \mathrm{pH} 7.2$. After washing with RPMI 1640 medium containing 5\% FBS and penicillin/streptomycin, tissue samples were digested for $2 \times 45$ min on a plate shaker at $37^{\circ} \mathrm{C}$ with RPMI 1640 medium supplemented with $5 \%$ FBS, penicillin/streptomycin and $0.5 \mathrm{mg} / \mathrm{mL}$ collagenase type VIII (Sigma-Aldrich). To collect lamina propria cells, samples were vortexed for $10 \mathrm{~s}$ after each incubation and passed through a $100 \mu \mathrm{m}$ nylon cell strainer. LP cell suspensions were subsequently washed with HBSS/HEPES and purified using a Percoll ${ }^{\circledR}$ density gradient (pH 7.2; GE Healthcare, Uppsala, Sweden). Purified LP cell suspensions were washed and resuspended in PBS/1\% BSA for flow cytometric analysis.

\subsection{Flow Cytometric Analysis of Immune Cells}

Spleen-, MLN-, and LP-derived single cell suspensions (0.5-1 × 106 cells/well) were incubated for 15 min on ice with anti-mouse CD16/CD32 (Mouse BD Fc Block; BD Biosciences) in PBS/1\% BSA $/ 5 \%$ FBS buffer to block non-specific binding sites. Subsequently, cells were extracellularly stained with CD4-PerCP-Cy5.5, CD69-APC, CXCR3-PE, CD25-Alexa Fluor ${ }^{\circledR} 488$, F4/80-APC-eFluor ${ }^{\circledR}$ 780, CD11c-PerCP-Cy5.5, CD103-APC, CD11b-PE, MHCII-FITC, CD45-PE-Cy7, CD19-PerCP-Cy5.5, CD45R/B220-FITC, latency-associated peptide (LAP)-PE-Cy7 (all purchased from eBioscience), T1ST2-FITC (MD Bioproducts, St. Paul, MN, USA) or CD138-APC (BD Biosciences) for $30 \mathrm{~min}$ on ice. Viable cells were distinguished using Fixable Viability Dye-eFluor ${ }^{\circledR} 780$ (eBioscience). Cells only stained for extracellular markers were fixed using IC Fixation Buffer (eBioscience). Cells additionally stained with intracellular markers were fixed and permeabilized using the FoxP3 Transcription Factor Staining Buffer Set (eBioscience) according to the manufacturer's protocol and then stained with FoxP3-PE-Cy7 or -APC (eBioscience). Stained cells were measured on the FACS Canto II (BD Biosciences) and analyzed with FlowLogic Software (Inivai Technologies). To increase LAP expression on the surface of MLN-derived lymphocytes, cells were polyclonally stimulated with anti-CD3 $(10 \mu \mathrm{g} / \mathrm{mL}) / \mathrm{CD} 28\left(1 \mu \mathrm{g} / \mathrm{mL}\right.$; eBioscience) for $48 \mathrm{~h}$ at $37{ }^{\circ} \mathrm{C}, 5 \% \mathrm{CO}_{2}$ prior to staining, and boosted afterwards with leukocyte activation cocktail (BD Biosciences) for $4 \mathrm{~h}$ at $37^{\circ} \mathrm{C}, 5 \% \mathrm{CO}_{2}$.

\subsection{Cytokine Measurements after ex vivo OVA-Specific Stimulation of Splenocytes}

Single cell splenocyte suspensions $\left(8 \times 10^{5}\right.$ cells/well) were cultured in U-bottom culture plates (Greiner, Frickenhausen, Germany) with either medium or OVA (50 $\mu \mathrm{g} / \mathrm{mL})$ for four days at $37^{\circ} \mathrm{C}, 5 \%$ $\mathrm{CO}_{2}$. Culture supernatant was collected and stored at $-20{ }^{\circ} \mathrm{C}$ until measurements of IFN $\gamma$, IL-13 and IL-10 by means of ELISA, as described elsewhere [17].

\subsection{Short-Chain Fatty Acid (SCFA) Analysis in Caecum}

Caecal content was collected, snap-frozen in liquid nitrogen and stored at $-80^{\circ} \mathrm{C}$ until further analysis. After thawing, samples were homogenized by vortexing and diluted in cold PBS (1:10). Samples were subsequently centrifuged, the supernatant was collected and concentrations of acetic, propionic, butyric, isobutyric, valeric and isovaleric acid were determined as previously described [18] by means of a Shimadzu GC2010 gas chromatograph (Shimadzu Corporation, Kyoto, Japan), using 2-ethylbutyric acid as internal standard. 


\subsection{Statistical Analysis}

Data are presented as mean \pm SEM, including individual data points, and differences between pre-selected groups were statistically determined with one-way ANOVA followed by a Bonferroni's multiple comparisons test. For plasma cells in the MLN, log-transformed data were used to obtain normality for one-way ANOVA. For the same reason, OVA-specific IgG1 and IgA levels were square root-transformed. As OVA-specific IgE levels were not normally distributed, data were presented as individual data points in a box-and-whisker Tukey plot and analyzed using Kruskal-Wallis test followed by a Dunn's multiple comparisons test for pre-selected groups. All statistical analyses were performed using GraphPad Prism software (version 7.03; GraphPad Software, San Diego, CA, USA) and results were considered statistically significant when $P<0.05$.

\section{Results}

3.1. Suppression of the Allergic Effector Response by Raw Milk is Retained after Skimming but Abolished after Heating the Milk

To determine whether milk processing affects the capacity of raw cow's milk to induce tolerance to a non-milk, food allergen, mice were orally treated with raw milk, pasteurized milk or skimmed milk before being sensitized and challenged with OVA. As expected, OVA-sensitized allergic mice showed an increased acute allergic skin response upon intradermal challenge compared to PBS-sensitized control mice (Figure 2A). Exposing mice to raw milk before OVA-sensitization significantly reduced the acute allergic skin response compared to PBS-treated allergic mice (Figure 2A). This protective effect was retained after skimming but abolished after pasteurization of the milk (Figure 2A). Since ALP is one of the first bioactive raw milk components losing activity upon heat treatment, we investigated whether spiking pasteurized milk with ALP would restore the allergy-protective effect. Interestingly, addition of ALP to pasteurized milk significantly lowered the acute allergic skin response compared to PBS-treated allergic mice and pasteurized milk-treated mice (Figure 2A). To study the extent of basophil activation, basophil surface expression of CD200R after stimulation of whole blood with OVA was determined. Even though no difference was observed in CD200R expression on basophils of OVA-sensitized allergic mice compared to PBS-sensitized control mice, CD200R expression was significantly reduced on basophils of mice treated with pasteurized milk + ALP compared to mice treated with pasteurized milk alone (Figure 2B), which is in line with the effects observed on the acute allergic skin response (Figure 2A). OVA-specific IgE levels and plasma cells were not significantly affected by exposure to the different milk types, but they did follow a similar pattern as the acute allergic skin response, with low levels in the raw milk, skimmed milk and pasteurized milk + ALP group and higher levels in the pasteurized milk group (Figure 2C,D). Unfortunately, OVA-specific IgE levels were not significantly increased in OVA-sensitized allergic mice compared to PBS-sensitized control mice (Figure 2C). However, OVA-specific IgG1 and IgA levels did (tend to) increase in these mice, demonstrating an immune response to OVA and supporting sensitization (Figure 2E,F). Functionality of $\mathrm{IgE}$ antibodies was furthermore confirmed using a murine bone marrow-derived mast cell degranulation assay (data not shown). For OVA-specific IgG1 and IgA, no differences between milk groups were observed (Figure 2E,F). 
A

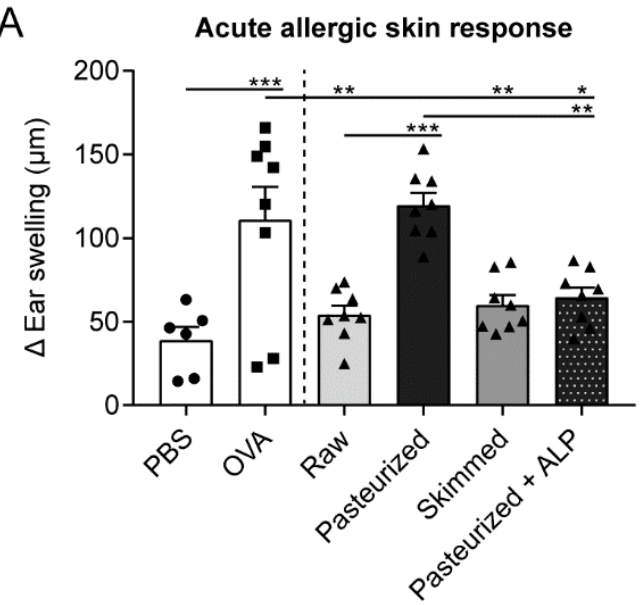

C

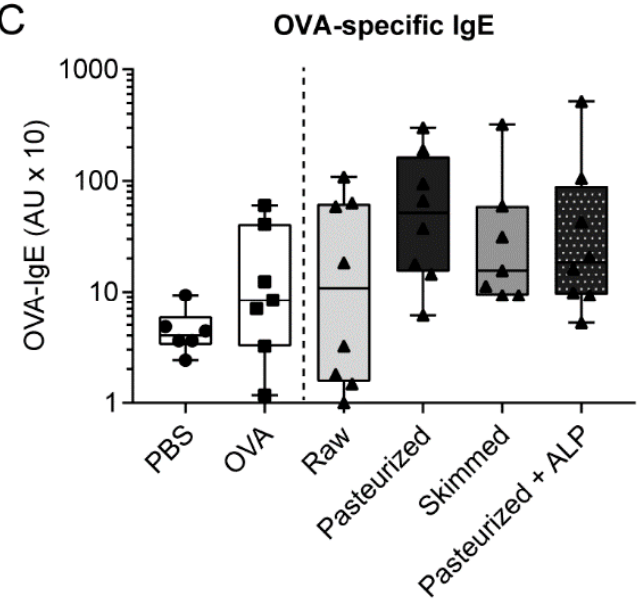

$E$

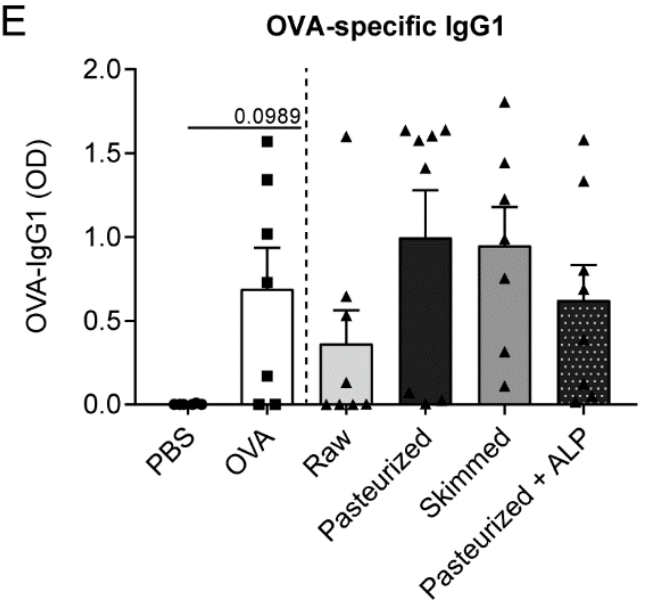

B

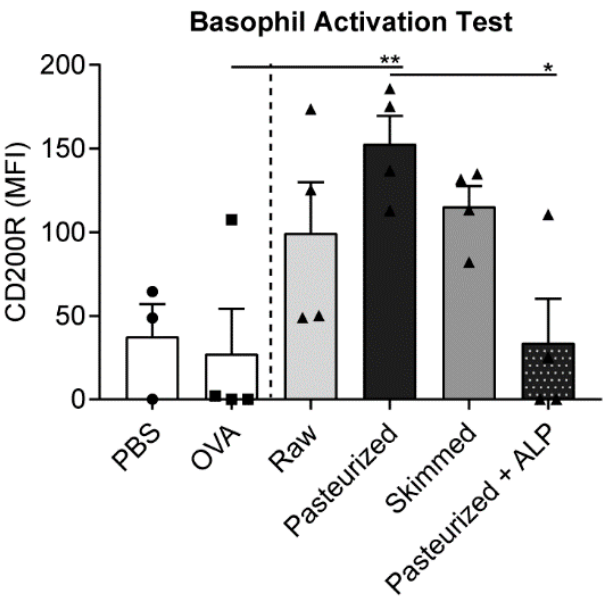

D

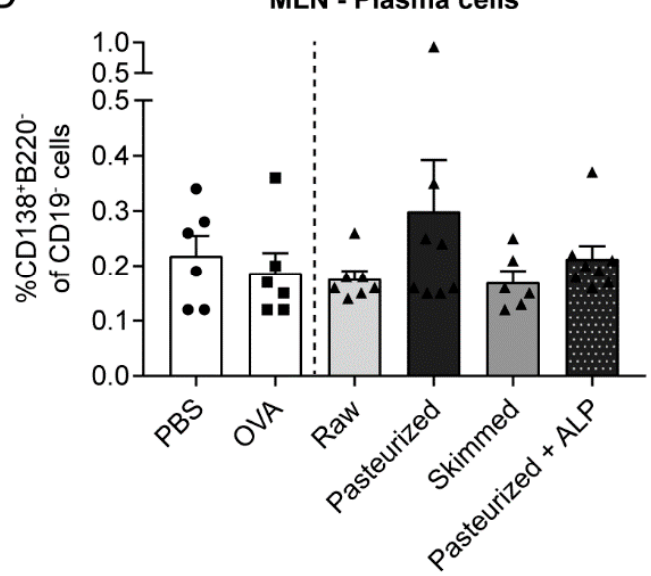

$\mathrm{F}$

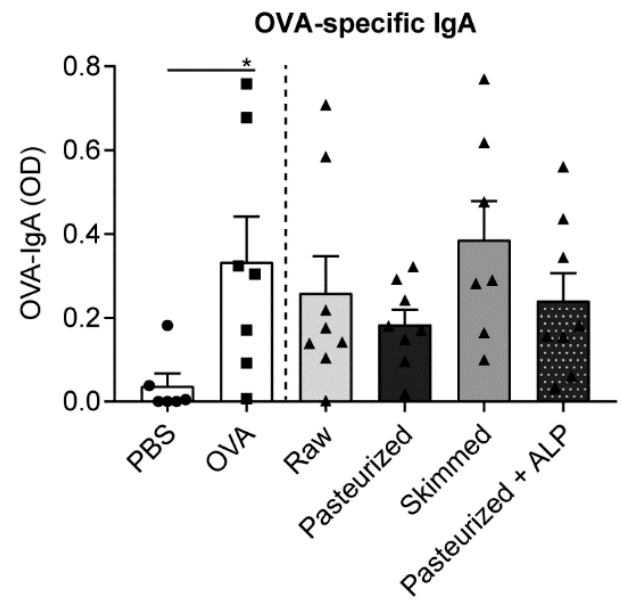

Figure 2. The protective effect of raw milk on the allergic effector response is retained by skimming but abolished by pasteurization of the milk. (A) The acute allergic skin response, expressed as $\Delta$ ear swelling, measured after intradermal challenge in the ear pinnae of both ears with OVA. (B) Basophil activation determined at Day 27 by surface expression of CD200R upon stimulation of whole blood with OVA (after subtracting baseline basophil activation). (C) Serum OVA-specific IgE levels measured $16 \mathrm{~h}$ after oral challenge. (D) Plasma cell $\left(\mathrm{CD} 138^{+} \mathrm{B} 220^{-}\right.$of $\mathrm{CD} 19^{-}$cells) frequency assessed in the MLN. (E) Serum OVA-specific IgG1 and (F) IgA levels measured $16 \mathrm{~h}$ after oral challenge. Data are presented 
as mean \pm SEM or as box-and-whisker Tukey plot when data were not normally distributed. In addition, individual data points are displayed, $n=6$ in PBS group and $n=6-8$ in all other groups. For the basophil activation test (B), blood samples from two mice were pooled, $n=3$ in the PBS group and $n=$ 4 in all other groups. ${ }^{*} P<0.05,{ }^{* *} P<0.01,{ }^{* * *} P<0.001$ as analyzed with one-way ANOVA followed by Bonferroni's multiple comparisons test for pre-selected groups (A,B,D,F) or Kruskal-Wallis test for non-parametric data followed by Dunn's multiple comparisons test for pre-selected groups (C). PBS, phosphate-buffered saline; OVA, ovalbumin; raw, raw cow's milk; pasteurized, pasteurized cow's milk; skimmed, skimmed raw cow's milk; pasteurized + ALP, pasteurized milk spiked with alkaline phosphatase; MFI, median fluorescence intensity; AU, arbitrary units; MLN, mesenteric lymph nodes; OD, optical density.

3.2. Low Th2-Related Cytokine Production by Splenocytes from Raw Milk-and Skimmed Milk-Treated Mice after ex vivo Stimulation with OVA

To investigate whether different milk types affect T helper cell phenotype, spleen and MLN cells were isolated and analyzed by flow cytometry. Percentages of Th1 and Th2 cells were not affected in OVA-sensitized allergic mice compared to PBS-sensitized control mice (Figure 3A-D). However, in the spleen of mice treated with pasteurized milk, Th1 cells tended to decrease compared to allergic mice treated with PBS (Figure 3A). Th2 cell frequency in the spleen did not differ between milk groups (Figure 3B). In the MLN, the percentage of Th1 cells did not differ between milk groups, whereas Th2 cell frequency was increased in mice treated with pasteurized milk + ALP compared to allergic mice treated with PBS (Figure 3D). To determine the functional response of splenocytes and MLN cells upon exposure to OVA, cytokine production was determined. Th1-related IFN $\gamma$ production by splenocytes was not affected by the different milk types (Figure 3E). For the Th2-related cytokine IL-13, low concentrations were observed in the raw milk, skimmed milk and pasteurized milk + ALP group (Figure 3F), which coincided with the effects observed on the acute allergic skin response (Figure 2A). Pasteurized milk treatment tended to increase the IL-13 production compared to raw milk treatment, whereas adding ALP to pasteurized milk tended to restore the low IL-13 levels (Figure 3F). Compared to raw milk, pasteurized milk also increased the production of IL-10 (Figure 3G), which was previously shown to act as a Th2 cytokine in this OVA-induced food allergy model [19]. Ex vivo stimulation of MLN cells with OVA did not induce detectable cytokine production (data not shown).

\subsection{Raw Milk and Skimmed Milk Induce Tolerance-Associated Cell Types in the MLN}

To assess whether the prevention of OVA-induced food allergic symptoms by raw milk, skimmed milk and pasteurized milk + ALP was associated with the induction of tolerance-associated cell types, changes in different dendritic cell (DC) and regulatory T cell (Treg) subsets were determined in the MLN. $\mathrm{DC}\left(\mathrm{CD} 11 \mathrm{c}^{+} \mathrm{MHCII}^{+}\right)$numbers tended to increase in raw milk-treated mice and increased in skimmed milk-treated mice compared to PBS-treated allergic mice (Figure 4A). More specific assessment of the DC subsets affected, revealed that both milk types mainly increased the tolerogenic $\mathrm{CD}_{103^{+}} \mathrm{CD}_{11 b^{+}}$ DC subpopulation (Figure 4B). Although $\mathrm{CD}_{103^{+}} \mathrm{DCs}$ are known for their capacity to induce FoxP3 ${ }^{+}$ Tregs in the MLN [20], no differences between groups were observed in the percentage of CD25 $5^{+}$FoxP3 ${ }^{+}$ Treg cells (Figure 4C). However, interestingly, the Treg subtype secreting TGF- $\beta$, also known as Th3 cells, tended to increase in the raw milk group compared to the pasteurized milk group (Figure 4D). 

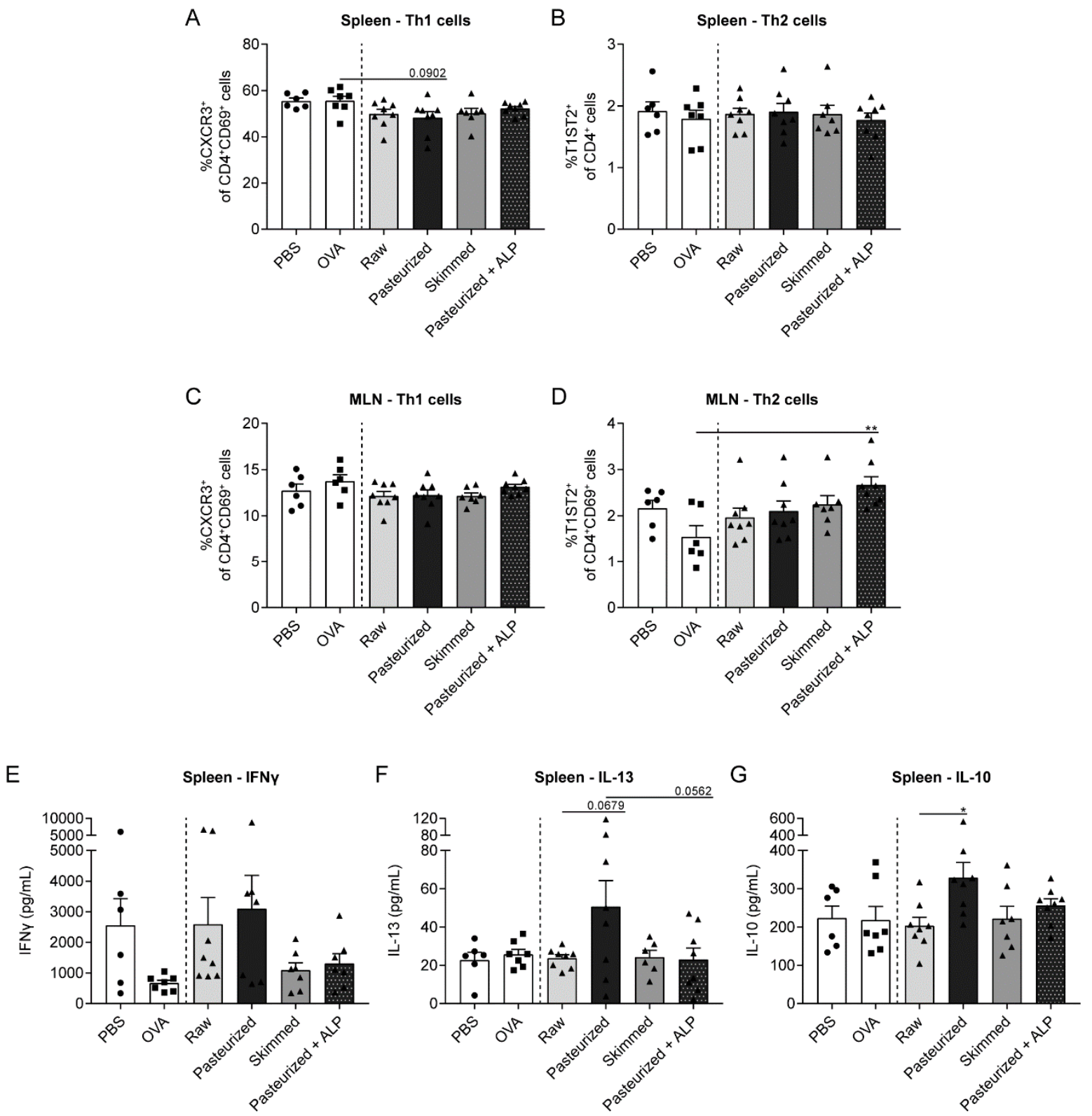

Figure 3. Th2-related cytokine concentrations produced by OVA-stimulated splenocytes were low in raw milk- and skimmed milk-treated mice. (A) The percentage of activated Th1 cells (CXCR3 ${ }^{+}$ of $\mathrm{CD}^{+} \mathrm{CD}^{+} 9^{+}$cells) and (B) Th2 cells (T1ST2 ${ }^{+}$of $\mathrm{CD} 4^{+}$cells) in the spleen. (C) The percentage of activated Th1 cells $\left(\mathrm{CXCR} 3^{+}\right.$of $\mathrm{CD} 4^{+} \mathrm{CD} 69^{+}$cells) and (D) activated Th2 cells (T1ST2 ${ }^{+}$of $\mathrm{CD} 4^{+} \mathrm{CD} 69^{+}$) in the MLN. (E) IFN $\gamma$, (F) IL-13 and (G) IL-10 concentrations measured in supernatant of ex vivo stimulated splenocytes with OVA (stimulated for four days, $37^{\circ} \mathrm{C}, 5 \% \mathrm{CO}_{2}$ ). Data are presented as mean \pm SEM, including individual data points, $n=6$ in PBS group and $n=6-8$ in all other groups. ${ }^{*} P<0.05,{ }^{* *} P<0.01$ as analyzed with one-way ANOVA followed by Bonferroni's multiple comparisons test for pre-selected groups. PBS, phosphate-buffered saline; OVA, ovalbumin; raw, raw cow's milk; pasteurized, pasteurized cow's milk; skimmed, skimmed raw cow's milk; pasteurized + ALP, pasteurized milk spiked with alkaline phosphatase; MLN, mesenteric lymph nodes. 
A

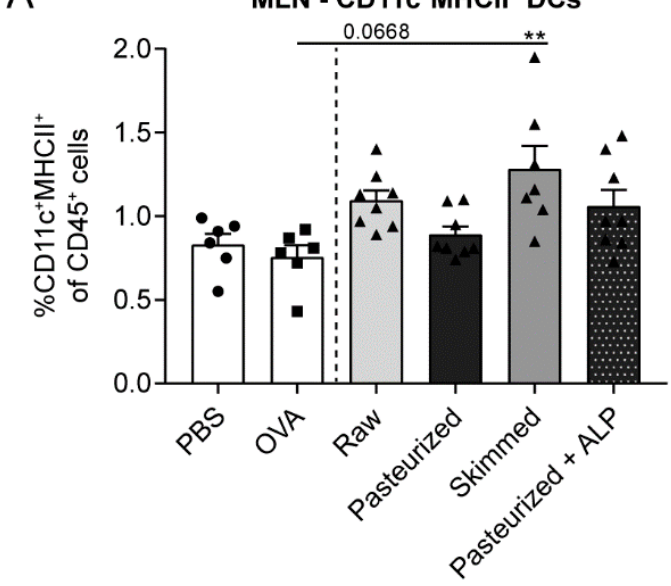

C

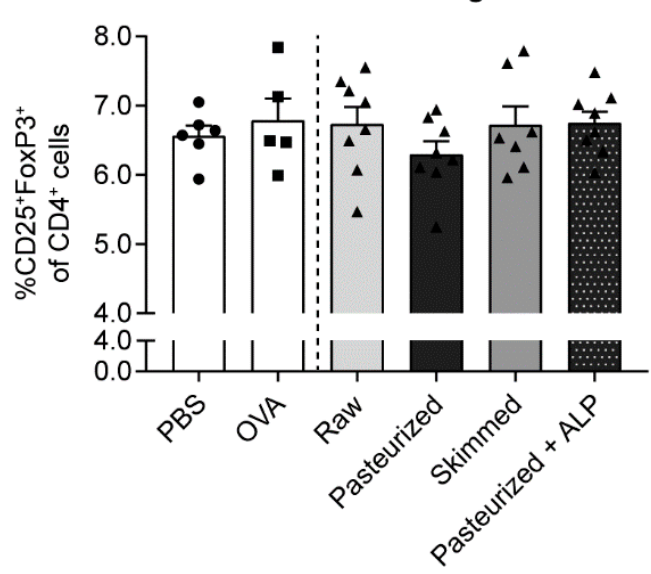

B MLN - CD103+CD11b+ DCs

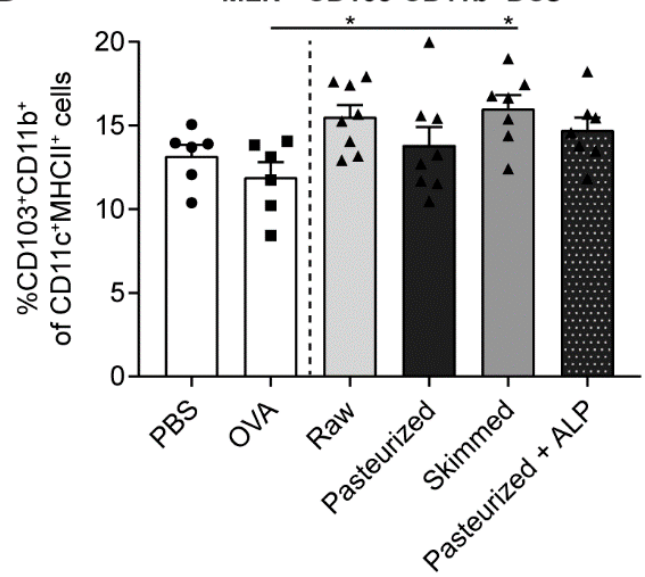

D

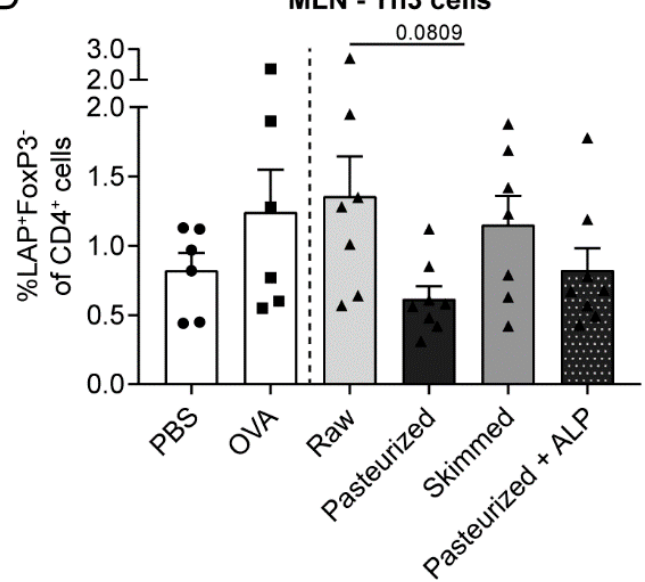

Figure 4. Induction of tolerance-associated cell types in the MLN of raw milk- and skimmed milk-treated mice. (A) Percentage of CD11 $\mathrm{c}^{+} \mathrm{MHCII}{ }^{+} \mathrm{DCs}\left(\mathrm{CD} 11 \mathrm{c}^{+} \mathrm{MHCII}^{+}\right.$of $\mathrm{CD}^{+} 5^{+}$cells), (B) $\mathrm{CD}^{+} 03^{+} \mathrm{CD}_{11 \mathrm{~b}^{+}}$ DCs $\left(\mathrm{CD} 103^{+} \mathrm{CD} 11 \mathrm{~b}^{+}\right.$of $\mathrm{CD} 11 \mathrm{c}^{+} \mathrm{MHCII}^{+}$cells), (C) $\mathrm{FoxP}^{+}$Treg cells $\left(\mathrm{CD} 25^{+} \mathrm{FoxP}^{+}\right.$of $\mathrm{CD}^{+}$cells) and (D) Th3 cells $\left(\mathrm{LAP}^{+} \mathrm{FoxP}^{-}\right.$of $\mathrm{CD}^{+}$cells) in the MLN. Data are presented as mean $\pm \mathrm{SEM}$, including individual data points, $n=6$ in PBS group and $n=5-8$ in all other groups. ${ }^{*} P<0.05,{ }^{* *} P<0.01$ as analyzed with one-way ANOVA followed by Bonferroni's multiple comparisons test for pre-selected groups. MLN, mesenteric lymph nodes; PBS, phosphate-buffered saline; OVA, ovalbumin; raw, raw cow's milk; pasteurized, pasteurized cow's milk; skimmed, skimmed raw cow's milk; pasteurized + ALP, pasteurized milk spiked with alkaline phosphatase. 
3.4. Increased Percentage of Tolerogenic DCs in MLN of Raw Milk-and Skimmed Milk-Treated Mice is Not Associated with Increased Treg Cell Frequency in the LP

Besides promoting the differentiation of naïve T cells into Treg cells, CD103 ${ }^{+}$DCs also induce the expression of gut-homing receptors on the surface of Treg cells [20]. To investigate whether the increased tolerogenic $\mathrm{CD}_{103}{ }^{+} \mathrm{CD} 11 \mathrm{~b}^{+} \mathrm{DC}$ subpopulation in the MLN of raw milk- and skimmed milk-treated mice was associated with increased Treg cell trafficking to the gut, lamina propria cells were isolated and analyzed by flow cytometry. However, CD25 $5^{+}$FoxP3 ${ }^{+}$Treg frequency did not differ between milk groups (Figure 5C) and also $\mathrm{CD} 11 \mathrm{c}^{+} \mathrm{MHCII}^{+} \mathrm{DC}$ and the $\mathrm{CD} 103^{+} \mathrm{CD} 11 \mathrm{~b}^{+}$subset showed no differences in the LP (Figure 5A,B).

A

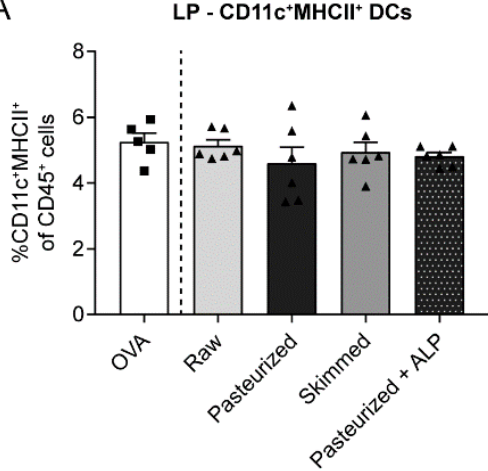

B

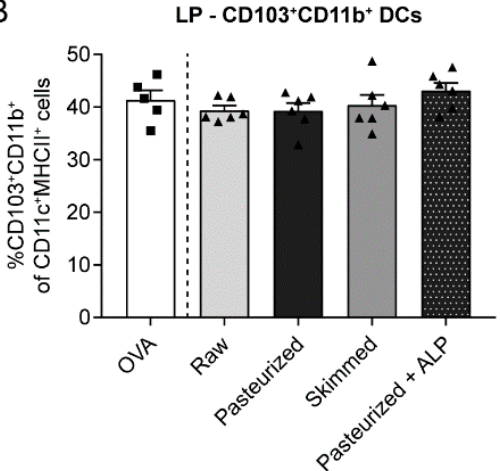

C

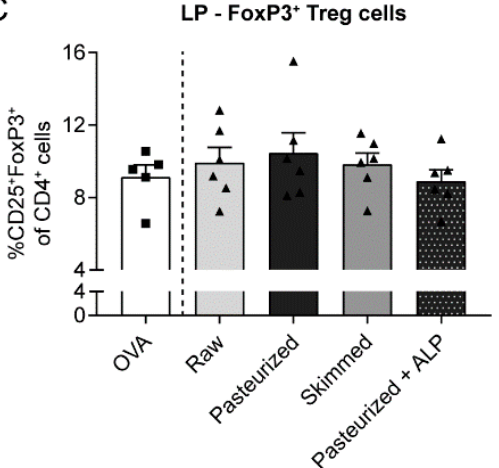

Figure 5. Different milk types did not affect tolerogenic DC and Treg cell frequency in the LP. (A) Percentage of $\mathrm{CD}_{11} \mathrm{c}^{+} \mathrm{MHCII}{ }^{+} \mathrm{DCs}\left(\mathrm{CD} 11 \mathrm{c}^{+} \mathrm{MHCII}^{+}\right.$of $\mathrm{CD} 45^{+}$cells), (B) $\mathrm{CD} 103^{+} \mathrm{CD} 11 \mathrm{~b}^{+} \mathrm{DCs}$

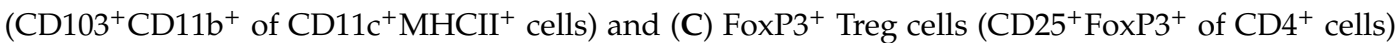
in the LP. Data are presented as mean \pm SEM, including individual data points, $n=5-6 /$ group. No significant differences were observed. LP, lamina propria; PBS, phosphate-buffered saline; OVA, ovalbumin; raw, raw cow's milk; pasteurized, pasteurized cow's milk; skimmed, skimmed raw cow's milk; pasteurized + ALP, pasteurized milk spiked with alkaline phosphatase.

\subsection{Different Milk Types Did Not Affect SCFA Concentrations}

Since modulation of the gut microbiome might be a way in which raw milk, skimmed milk and pasteurized milk + ALP induced tolerance to OVA, metabolic activity of the gut microbiome was assessed by determining SCFA concentrations in the caecum of the mice. Total SCFA concentrations were not significantly different between groups, but skimmed milk- and pasteurized milk + ALP-treated mice showed the highest levels (Figure 6A). Regarding individual SCFA, a similar pattern was observed for butyric acid and acetic acid concentrations, although again differences did not reach significance (Figure 6B,C). For propionic acid, concentrations were comparable in each milk group (Figure 6D). 
A

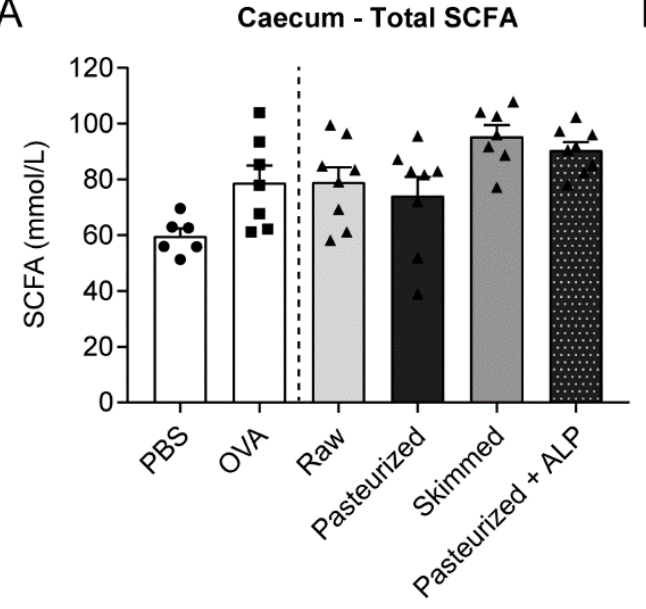

C

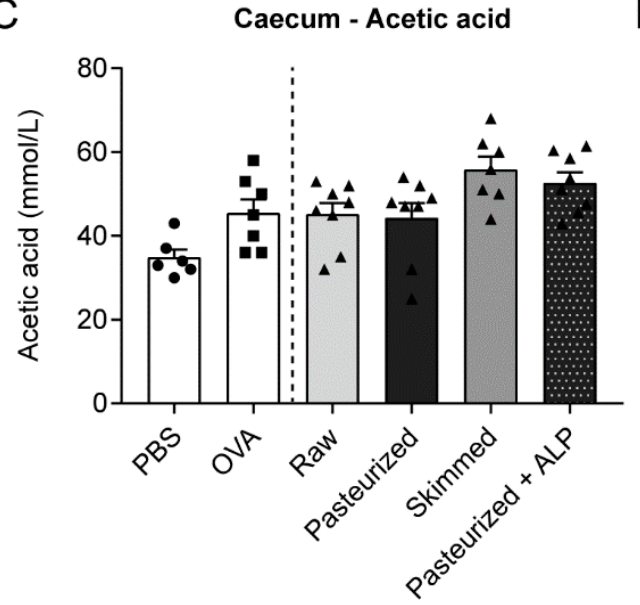

B

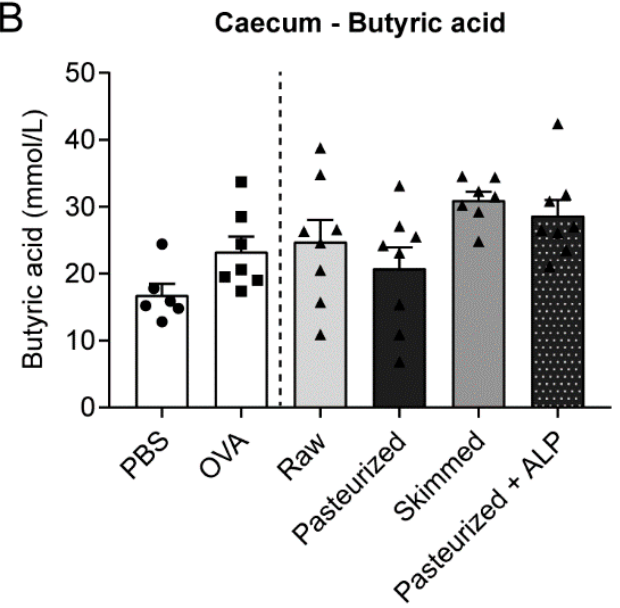

D

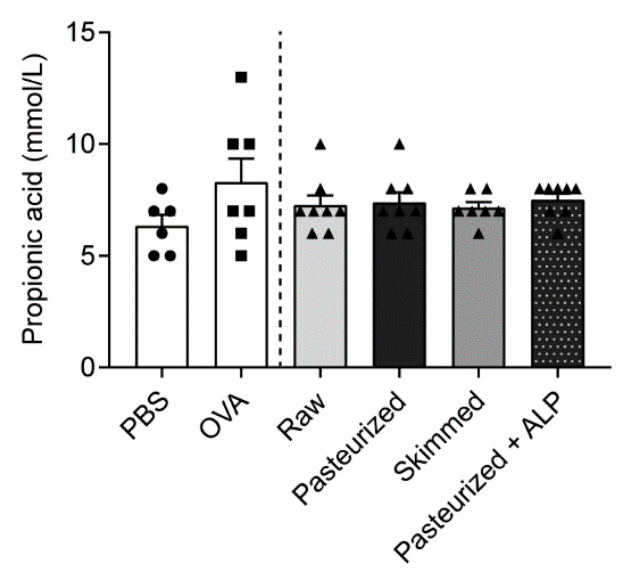

Figure 6. No differences in SCFA concentrations between milk groups. (A) Total SCFA concentrations and individual concentrations of (B) butyric acid, (C) acetic acid and (D) propionic acid measured in caecal content. Data are presented as mean \pm SEM, including individual data points, $n=6$ in PBS group and $n=7-8$ in all other groups. No significant differences were observed. SCFA, short-chain fatty acids; PBS, phosphate-buffered saline; OVA, ovalbumin; raw, raw cow's milk; pasteurized, pasteurized cow's milk; skimmed, skimmed raw cow's milk; pasteurized + ALP, pasteurized milk spiked with alkaline phosphatase.

\section{Discussion}

We previously showed that raw, unprocessed cow's milk induces tolerance to OVA, an unrelated, non-milk, food allergen, in a murine food allergy model [11]. In the present study, we demonstrated that this protective effect is retained after skimming but abolished after pasteurization of the milk. Similar to raw cow's milk, skimmed raw milk reduced the acute allergic skin response after intradermal challenge with OVA. This coincided with low levels of OVA-specific IgE and Th2-related cytokines. An increase in $\mathrm{CD}_{103}{ }^{+} \mathrm{CD} 11 \mathrm{~b}^{+}$DCs and TGF- $\beta$-producing Treg cells in the MLN, both associated with tolerance induction, might underlie the allergy-protective effects of raw and skimmed raw cow's milk. In addition, this study provides a first indication that adding ALP to heat-treated milk might be an interesting preventive strategy since spiking pasteurized milk with ALP restored the allergy-protective effects.

Although several epidemiological studies have shown the potency of raw cow's milk to reduce/prevent allergic diseases [5-9], its consumption is limited due to the potential presence of pathogens. The risks of diseases outbreaks by pathogens such as Mycobacterium tuberculosis, Listeria, 
Salmonella, Campylobacter, Enterohemorrhagic Escherichia coli and Shigatoxigenic Escherichia coli are the reason for governmental agencies to prohibit the sale of raw cow's milk [12]. To prevent these potential risks, milk used for commercial purposes is processed. This means that, upon collection, raw milk undergoes various processing steps such as milk fat standardization, homogenization and heat treatment. These processing steps have profound effects on the milk structure and are shown to be detrimental to the allergy-protective effects $[5,10,14]$.

Milk processing predominantly affects the fat content of the milk and the heat-sensitive milk components $[21,22]$. Since milk processing also abolishes the allergy-protective effects of raw cow's milk, this suggests that these constituents contribute to the observed protection. Indeed, both Wijga et al. (2003) and Waser et al. (2006) showed that frequent consumption of products containing milk fat was associated with a reduced asthma risk $[8,23]$. In addition, Brick et al. $(2016)$ concluded that part of the asthma-protective effect of raw cow's milk was explained by a higher fat content and, particularly, higher $n-3$ polyunsaturated fatty acids levels compared to shop milk [14]. However, at the same time, there are also studies where the total fat content was not significantly related to asthma [5]. Epidemiological evidence also exists for a potential contribution of heat-sensitive raw milk components. Loss et al. (2011) demonstrated that raw farm milk, but not boiled farm milk, was inversely associated with asthma, hay fever and atopy. The heat-sensitive whey protein fraction of raw milk was implied to underlie these effects [5]. However, since these are all associations, proof of causality is needed to confirm the protective effects of these different raw milk constituents.

In the present study, we therefore investigated the effect of skimmed raw milk and pasteurized milk in a murine OVA-induced food allergy model. Skimmed milk was as allergy-protective as raw milk, suggesting that the fat content of the milk does not contribute to a large extent to the allergy-protective effects of raw cow's milk. Our results are in contrast with most of the epidemiological findings $[8,14,23]$, emphasizing the importance of demonstrating a cause-effect relationship. On the other hand, the discrepancy could also be caused by the fact that these epidemiological studies mainly focused on asthma, whereas our study focused on food allergy. Different disease pathogenesis might underlie the different outcomes.

In contrast to skimming, pasteurization abolished the allergy-protective effects of raw cow's milk in the murine food allergy model used. This is in accordance with epidemiological evidence and with our previous results in a murine asthma model, both showing a loss of protection after heat treatment $[5,10]$. By comparing milk from the same origin, differing in only one processing step we can conclude with certainty that pasteurization is harmful to the allergy-protective capacity of raw cow's milk. The importance of heat-sensitive milk components, such as proteins, microRNAs and microbes, is thereby emphasized. Particularly, the heat-sensitive whey protein fraction of raw milk is often mentioned as source of the allergy-protective components. The major whey proteins, namely $\alpha$-lactalbumin, $\beta$-lactoglobulin and bovine serum albumin, do not have immunomodulatory functionalities that can directly be linked to the allergy-protective effects of raw cow's milk, but several less abundant whey proteins such as immunoglobulins, lactoferrin, TGF- $\beta$ and IL-10 theoretically do [24-26].

A first step towards identifying the potential allergy-protective whey proteins was made by Brick et al. (2017), who investigated the effect of processing intensity on immunologically active milk proteins [27]. As expected, a decrease in the number and abundance of detectable native whey proteins was observed with increasing heat load. Interestingly, the subsequent proteomic analysis categorized the milk samples into two clusters; high (boiled, ultra-high temperature and extended shelf life) and no/low heat treatment (raw, skimmed, pasteurized) [27]. Although pasteurized milk clustered together with raw and skimmed milk, indicating similar native protein patterns, it did not confer protection in our study. One could therefore argue that the overall native protein pattern looks similar but that minor differences still have major consequences for the allergy-protective capacity of the milk. One could also argue that even though pasteurization does not lead to denaturation or chemical modifications of whey proteins, it might lead to loss of functionality. 
Although the effect of processing intensity on immunologically active whey proteins is very relevant, it does not provide a direct link to allergic diseases. To provide this link, specific whey proteins can be added to heat-treated milk to see whether they could restore the allergy-protective effect. As a first proof-of-concept, we spiked pasteurized milk with ALP and we assessed the effects on OVA-induced food allergic symptoms. ALP is probably best-known for its function in dairy industry as indicator of successful pasteurization. Upon pasteurization, ALP becomes inactivated and loses its activity, making it an ideal indicator of product safety [28]. Since ALP is one of the first bioactive raw milk components losing activity upon heat treatment, it is also a likely allergy-protective candidate. Oral administration of ALP was already shown to be effective in reducing inflammatory diseases [29-32], but whether it can also affect allergic diseases has, to our knowledge, never been studied.

Surprisingly, ALP was able to fully restore the allergy-protective effect in the food allergy model used. On practically every parameter assessed, ALP added to pasteurized milk showed similar protective effects as raw milk and skimmed raw milk. As this was a first proof-of-concept, 10 times higher ALP concentrations than present in raw cow's milk were added to pasteurized milk. We can therefore not yet conclude that ALP is the component underlying the allergy-protective effects of raw cow's milk, but it seems to be a promising candidate to be used as supplement to heat-treated milk.

In addition to the components involved, this study also provides some indication of the underlying mechanisms. The fact that mice orally treated for eight days with raw cow's milk were protected against OVA-induced allergic symptoms indicates that they developed oral tolerance to OVA. This oral tolerance was induced in the absence of the allergen, demonstrating that raw cow's milk has the capacity to induce tolerance via generic immunomodulation. The many immunomodulatory components present in raw cow's milk are likely to create a tolerogenic environment favoring unresponsiveness upon allergen exposure. Raw cow's milk is hypothesized to promote Treg cell development, to modulate the gut microbiome and to enhance intestinal barrier function [24-26]. However, none of these effects have actually been demonstrated after drinking raw milk.

The present study therefore tried to get more insight into some of these proposed mechanisms. Treg cells are identified as key players in inducing and maintaining oral tolerance [33]. However, in our study, the percentage of $\mathrm{CD}_{2} 5^{+} \mathrm{FoxP}^{+}$Treg cells in the MLN was not affected by raw milk treatment. Interestingly, raw milk did increase the Treg subtype secreting TGF- $\beta$ compared to pasteurized milk. The importance of these Th3 cells is demonstrated in a study showing reduced numbers in the intestine of food allergic children [34].

Induction of FoxP3 ${ }^{+}$Treg cells occurs in the MLN by $\mathrm{CD} 103^{+} \mathrm{DC}$ s under the influence of retinoic acid and TGF- $\beta[35,36]$. CD103 ${ }^{+}$DCs originate in the LP and migrate to the MLNs in a CCR7-dependent manner after acquiring antigen [37]. This DC trafficking from the intestinal mucosa to the MLNs is crucial for oral tolerance induction $[38,39]$. Interestingly, while raw milk exposure did not significantly affect $\mathrm{CD} 25^{+} \mathrm{FoxP}^{+}$Treg cells in the MLN, it did increase the tolerogenic $\mathrm{CD} 103^{+} \mathrm{CD} 11 \mathrm{~b}^{+}$ DC subpopulation. Besides promoting the development of FoxP3 ${ }^{+}$Treg cells, these DCs also induce the expression of gut-homing receptors on the cell surface of FoxP3 ${ }^{+}$Treg cells [35], indicating that the Treg cells might have migrated to the gut. However, also in the LP, FoxP3 ${ }^{+}$Treg cell frequency was not increased by raw milk. Examining effects on Treg cell populations directly after raw milk exposure, instead of at the end of the study, might be of importance, since farm milk exposure was previously shown to be associated with increased $\mathrm{FoxP}^{+}$Treg cell numbers in children [40].

Regarding the potential immune modulation via the gut microbiome, results were not convincing for raw milk. Caecal SCFA concentrations, as indicator of metabolic activity of the gut microbiome, were not altered compared to other milk groups. However, effects on the gut microbiota itself were not assessed and the timing of measuring SCFA levels might also be crucial in this case. Highest SCFA concentrations, particularly butyric acid and acetic acid, were observed after exposure to skimmed raw milk and ALP. Since oral administration of ALP was previously shown to preserve normal gut microbiome homeostasis [41-43], it is tempting to speculate that this feature contributes to its allergy-protective effect. 
A limitation of the current study is the lack of a significant IgE response in OVA-sensitized allergic mice compared to PBS-sensitized control mice. However, although significance was not reached, most of the animals in the OVA group did show higher OVA-IgE levels than animals in the PBS group. We would like to emphasize that serum IgE levels do not always correlate with the severity of the allergic response and that allergic symptoms are not solely induced by IgE [44-46]. The acute allergic skin response is the primary parameter of food allergic symptoms in the validated mouse model used. This response is acknowledged as a true acute allergic response and recognized as a translatable readout $[47,48]$.

In summary, we demonstrated that the suppression of food allergic symptoms by raw cow's milk is retained after skimming but abolished after pasteurization of the milk. The data presented therefore indicate that not the fat content, but the heat-sensitive milk components are underlying the allergy-protective effects of raw cow's milk. The protection by raw and skimmed raw cow's milk was accompanied by an induction of tolerance-associated cell types in the MLN. In addition, we showed that ALP has the capacity to restore the allergy-protective effects abolished by heat treatment. This study thereby provides, for the first time, a direct link between one of the immunologically active whey proteins present in raw cow's milk and the suppression of allergic symptoms. Although its potency and mechanism of action still need to be determined, ALP is a promising raw milk component to be added to heat-treated milk. Hence, this research represents an attractive preventive strategy for allergic diseases as alternative to raw milk consumption.

Author Contributions: Conceptualization, S.A., J.T.R., G.H., J.G. and B.C.A.M.v.E.; Funding acquisition, G.H., J.G. and B.C.A.M.v.E.; Investigation, S.A., J.T.R. and M.A.P.D.; Methodology, S.A. and B.C.A.M.v.E.; Project administration, S.A. and B.C.A.M.v.E.; Supervision, S.A., J.G. and B.C.A.M.v.E.; Visualization, S.A.; Writing—original draft, S.A.; and Writing—review and editing, J.T.R., G.H., J.G. and B.C.A.M.v.E.

Funding: This research was financially supported by Danone Nutricia Research.

Acknowledgments: The authors would like to thank W. Seinen (Utrecht University, Utrecht, The Netherlands) for kindly providing bovine intestinal alkaline phosphatase and B.R.J. Blokhuis (Utrecht University) for his technical assistance.

Conflicts of Interest: J.T.R. and G.H. are employed at Danone Nutricia Research. J.G. and B.C.A.M.v.E. are partly employed at Danone Nutricia Research. All other authors report no potential conflicts of interest.

\section{References}

1. West, C.E.; D'Vaz, N.; Prescott, S.L. Dietary immunomodulatory factors in the development of immune tolerance. Curr. Allergy Asthma Rep. 2011, 11, 325-333. [CrossRef] [PubMed]

2. Thijs, C.; Muller, A.; Rist, L.; Kummeling, I.; Snijders, B.E.; Huber, M.; van Ree, R.; Simoes-Wust, A.P.; Dagnelie, P.C.; Van Den Brandt, P.A. Fatty acids in breast milk and development of atopic eczema and allergic sensitisation in infancy. Allergy 2011, 66, 58-67. [CrossRef] [PubMed]

3. Verhasselt, V.; Milcent, V.; Cazareth, J.; Kanda, A.; Fleury, S.; Dombrowicz, D.; Glaichenhaus, N.; Julia, V. Breast milk-mediated transfer of an antigen induces tolerance and protection from allergic asthma. Nat. Med. 2008, 14, 170-175. [CrossRef] [PubMed]

4. Moro, G.; Arslanoglu, S.; Stahl, B.; Jelinek, J.; Wahn, U.; Boehm, G. A mixture of prebiotic oligosaccharides reduces the incidence of atopic dermatitis during the first six months of age. Arch. Dis. Child. 2006, 91, 814-819. [CrossRef] [PubMed]

5. Loss, G.; Apprich, S.; Waser, M.; Kneifel, W.; Genuneit, J.; Buchele, G.; Weber, J.; Sozanska, B.; Danielewicz, H.; Horak, E.; et al. The protective effect of farm milk consumption on childhood asthma and atopy: The GABRIELA study. J. Allergy Clin. Immunol. 2011, 128. [CrossRef] [PubMed]

6. $\quad$ Ege, M.J.; Frei, R.; Bieli, C.; Schram-Bijkerk, D.; Waser, M.; Benz, M.R.; Weiss, G.; Nyberg, F.; van Hage, M.; Pershagen, G.; et al. Not all farming environments protect against the development of asthma and wheeze in children. J. Allergy Clin. Immunol. 2007, 119, 1140-1147. [CrossRef] [PubMed]

7. Riedler, J.; Braun-Fahrlander, C.; Eder, W.; Schreuer, M.; Waser, M.; Maisch, S.; Carr, D.; Schierl, R.; Nowak, D.; von Mutius, E.; et al. Exposure to farming in early life and development of asthma and allergy: A cross-sectional survey. Lancet 2001, 358, 1129-1133. [CrossRef] 
8. Waser, M.; Michels, K.B.; Bieli, C.; Floistrup, H.; Pershagen, G.; von Mutius, E.; Ege, M.; Riedler, J.; Schram-Bijkerk, D.; Brunekreef, B.; et al. Inverse association of farm milk consumption with asthma and allergy in rural and suburban populations across Europe. Clin. Exp. Allergy 2007, 37, 661-670. [CrossRef]

9. Perkin, M.R.; Strachan, D.P. Which aspects of the farming lifestyle explain the inverse association with childhood allergy? J. Allergy Clin. Immunol. 2006, 117, 1374-1381. [CrossRef]

10. Abbring, S.; Verheijden, K.A.T.; Diks, M.A.P.; Leusink-Muis, A.; Hols, G.; Baars, T.; Garssen, J.; van Esch, B.C.A.M. Raw Cow's Milk Prevents the Development of Airway Inflammation in a Murine House Dust Mite-Induced Asthma Model. Front. Immunol. 2017, 8, 1045. [CrossRef]

11. Abbring, S.; Wolf, J.; Ayechu Muruzabal, V.; Diks, M.A.P.; Alashkar Alhamwe, B.; Alhamdan, F.; Harb, H.; Renz, H.; Garn, H.; Garssen, J.; et al. Raw cow's milk suppresses allergic symptoms in a murine model for food allergy-A potential role for epigenetic modifications. Nutrients (under review).

12. Committee on Infectious Diseases \& Committee on Nutrition \& American Academy of Pediatrics. Consumption of Raw or Unpasteurized Milk and Milk Products by Pregnant Women and Children. Pediatrics 2014, 133, 175-179. [CrossRef] [PubMed]

13. Verordnung über die Güteprüfung und Bezahlung der Anlieferungsmilch (Milch-Güteverordnung). Available online: http://www.gesetze-im-internet.de/milchg_v/index.html (accessed on 26 March 2019).

14. Brick, T.; Schober, Y.; Bocking, C.; Pekkanen, J.; Genuneit, J.; Loss, G.; Dalphin, J.C.; Riedler, J.; Lauener, R.; Nockher, W.A.; et al. Omega-3 fatty acids contribute to the asthma-protective effect of unprocessed cow's milk. J. Allergy Clin. Immunol. 2016, 137, 1699-1706.e13. [CrossRef] [PubMed]

15. Torrero, M.N.; Larson, D.; Hubner, M.P.; Mitre, E. CD200R surface expression as a marker of murine basophil activation. Clin. Exp. Allergy 2009, 39, 361-369. [CrossRef] [PubMed]

16. Deurloo, D.T.; van Esch, B.C.; Hofstra, C.L.; Nijkamp, F.P.; van Oosterhout, A.J. CTLA4-IgG reverses asthma manifestations in a mild but not in a more "severe" ongoing murine model. Am. J. Respir. Cell Mol. Biol. 2001, 25, 751-760. [CrossRef] [PubMed]

17. Abbring, S.; Kusche, D.; Roos, T.C.; Diks, M.A.P.; Hols, G.; Garssen, J.; Baars, T.; van Esch, B.C.A.M. Milk processing increases the allergenicity of cow's milk-preclinical evidence supported by a human proof-of-concept provocation pilot. Clin. Exp. Allergy 2019. [CrossRef] [PubMed]

18. Bakker-Zierikzee, A.M.; Alles, M.S.; Knol, J.; Kok, F.J.; Tolboom, J.J.; Bindels, J.G. Effects of infant formula containing a mixture of galacto- and fructo-oligosaccharides or viable Bifidobacterium animalis on the intestinal microflora during the first 4 months of life. Br. J. Nutr. 2005, 94, 783-790. [CrossRef]

19. Polukort, S.H.; Rovatti, J.; Carlson, L.; Thompson, C.; Ser-Dolansky, J.; Kinney, S.R.; Schneider, S.S.; Mathias, C.B. IL-10 Enhances IgE-Mediated Mast Cell Responses and Is Essential for the Development of Experimental Food Allergy in IL-10-Deficient Mice. J. Immunol. 2016, 196, 4865-4876. [CrossRef]

20. Coombes, J.L.; Siddiqui, K.R.; Arancibia-Carcamo, C.V.; Hall, J.; Sun, C.M.; Belkaid, Y.; Powrie, F. A functionally specialized population of mucosal CD103+ DCs induces Foxp3+ regulatory T cells via a TGF-beta and retinoic acid-dependent mechanism. J. Exp. Med. 2007, 204, 1757-1764. [CrossRef]

21. Michalski, M.C.; Januel, C. Does homogenization affect the human health properties of cow's milk? Trends Food Sci. Technol. 2006, 17, 423-437. [CrossRef]

22. Niero, G.; Penasa, M.; Berard, J.; Kreuzer, M.; Cassandro, M.; De Marchi, M. Technical note: Development and validation of an HPLC method for the quantification of tocopherols in different types of commercial cow milk. J. Dairy Sci. 2018, 101, 6866-6871. [CrossRef] [PubMed]

23. Wijga, A.H.; Smit, H.A.; Kerkhof, M.; de Jongste, J.C.; Gerritsen, J.; Neijens, H.J.; Boshuizen, H.C.; Brunekreef, B.; PIAMA. Association of consumption of products containing milk fat with reduced asthma risk in pre-school children: The PIAMA birth cohort study. Thorax 2003, 58, 567-572. [CrossRef] [PubMed]

24. Van Neerven, R.J.; Knol, E.F.; Heck, J.M.; Savelkoul, H.F. Which factors in raw cow's milk contribute to protection against allergies? J. Allergy Clin. Immunol. 2012, 130, 853-858. [CrossRef] [PubMed]

25. Abbring, S.; Hols, G.; Garssen, J.; van Esch, B.C.A.M. Raw cow's milk consumption and allergic diseases-The potential role of bioactive whey proteins. Eur. J. Pharmacol. 2019, 843, 55-65. [CrossRef] [PubMed]

26. Perdijk, O.; van Splunter, M.; Savelkoul, H.F.J.; Brugman, S.; van Neerven, R.J.J. Cow's Milk and Immune Function in the Respiratory Tract: Potential Mechanisms. Front. Immunol. 2018, 9, 143. [CrossRef]

27. Brick, T.; Ege, M.; Boeren, S.; Bock, A.; von Mutius, E.; Vervoort, J.; Hettinga, K. Effect of Processing Intensity on Immunologically Active Bovine Milk Serum Proteins. Nutrients 2017, 9, 963. [CrossRef] 
28. Rankin, S.A.; Christiansen, A.; Lee, W.; Banavara, D.S.; Lopez-Hernandez, A. Invited review: The application of alkaline phosphatase assays for the validation of milk product pasteurization. J. Dairy Sci. 2010, 93, 5538-5551. [CrossRef] [PubMed]

29. Beumer, C.; Wulferink, M.; Raaben, W.; Fiechter, D.; Brands, R.; Seinen, W. Calf intestinal alkaline phosphatase, a novel therapeutic drug for lipopolysaccharide (LPS)-mediated diseases, attenuates LPS toxicity in mice and piglets. J. Pharmacol. Exp. Ther. 2003, 307, 737-744. [CrossRef]

30. Tuin, A.; Poelstra, K.; de Jager-Krikken, A.; Bok, L.; Raaben, W.; Velders, M.P.; Dijkstra, G. Role of alkaline phosphatase in colitis in man and rats. Gut 2009, 58, 379-387. [CrossRef]

31. Whitehouse, J.S.; Riggle, K.M.; Purpi, D.P.; Mayer, A.N.; Pritchard, K.A., Jr.; Oldham, K.T.; Gourlay, D.M. The protective role of intestinal alkaline phosphatase in necrotizing enterocolitis. J. Surg. Res. 2010, 163, 79-85. [CrossRef]

32. Lalles, J.P. Intestinal alkaline phosphatase: Multiple biological roles in maintenance of intestinal homeostasis and modulation by diet. Nutr. Rev. 2010, 68, 323-332. [CrossRef] [PubMed]

33. Akdis, M.; Blaser, K.; Akdis, C.A. T regulatory cells in allergy: Novel concepts in the pathogenesis, prevention, and treatment of allergic diseases. J. Allergy Clin. Immunol. 2005, 116, 961-968. [CrossRef] [PubMed]

34. Perez-Machado, M.A.; Ashwood, P.; Thomson, M.A.; Latcham, F.; Sim, R.; Walker-Smith, J.A.; Murch, S.H. Reduced transforming growth factor-beta1-producing $\mathrm{T}$ cells in the duodenal mucosa of children with food allergy. Eur. J. Immunol. 2003, 33, 2307-2315. [CrossRef]

35. Scott, C.L.; Aumeunier, A.M.; Mowat, A.M. Intestinal CD103+ dendritic cells: Master regulators of tolerance? Trends Immunol. 2011, 32, 412-419. [CrossRef] [PubMed]

36. Mucida, D.; Pino-Lagos, K.; Kim, G.; Nowak, E.; Benson, M.J.; Kronenberg, M.; Noelle, R.J.; Cheroutre, H. Retinoic acid can directly promote TGF-beta-mediated Foxp3(+) Treg cell conversion of naive T cells. Immunity 2009, 30, 471-472. [CrossRef] [PubMed]

37. Jang, M.H.; Sougawa, N.; Tanaka, T.; Hirata, T.; Hiroi, T.; Tohya, K.; Guo, Z.; Umemoto, E.; Ebisuno, Y.; Yang, B.G.; et al. CCR7 is critically important for migration of dendritic cells in intestinal lamina propria to mesenteric lymph nodes. J. Immunol. 2006, 176, 803-810. [CrossRef]

38. Worbs, T.; Forster, R. A key role for CCR7 in establishing central and peripheral tolerance. Trends Immunol. 2007, 28, 274-280. [CrossRef] [PubMed]

39. Spahn, T.W.; Weiner, H.L.; Rennert, P.D.; Lugering, N.; Fontana, A.; Domschke, W.; Kucharzik, T. Mesenteric lymph nodes are critical for the induction of high-dose oral tolerance in the absence of Peyer's patches. Eur. J. Immunol. 2002, 32, 1109-1113. [CrossRef]

40. Lluis, A.; Depner, M.; Gaugler, B.; Saas, P.; Casaca, V.I.; Raedler, D.; Michel, S.; Tost, J.; Liu, J.; Genuneit, J.; et al. Increased regulatory $\mathrm{T}$-cell numbers are associated with farm milk exposure and lower atopic sensitization and asthma in childhood. J. Allergy Clin. Immunol. 2014, 133, 551-559. [CrossRef]

41. Bates, J.M.; Akerlund, J.; Mittge, E.; Guillemin, K. Intestinal alkaline phosphatase detoxifies lipopolysaccharide and prevents inflammation in zebrafish in response to the gut microbiota. Cell Host Microbe 2007, 2, 371-382. [CrossRef]

42. Malo, M.S.; Alam, S.N.; Mostafa, G.; Zeller, S.J.; Johnson, P.V.; Mohammad, N.; Chen, K.T.; Moss, A.K.; Ramasamy, S.; Faruqui, A.; et al. Intestinal alkaline phosphatase preserves the normal homeostasis of gut microbiota. Gut 2010, 59, 1476-1484. [CrossRef] [PubMed]

43. Lalles, J.P. Intestinal alkaline phosphatase: Novel functions and protective effects. Nutr. Rev. 2014, 72, 82-94. [CrossRef]

44. Schouten, B.; van Esch, B.C.; van Thuijl, A.O.; Blokhuis, B.R.; Groot Kormelink, T.; Hofman, G.A.; Moro, G.E.; Boehm, G.; Arslanoglu, S.; Sprikkelman, A.B.; et al. Contribution of IgE and immunoglobulin free light chain in the allergic reaction to cow's milk proteins. J Allergy Clin Immunol. 2010, 125, 1308-1314. [CrossRef]

45. Sampson, H.A.; Aceves, S.; Bock, S.A.; James, J.; Jones, S.; Lang, D.; Nadeau, K.; Nowak-Wegrzyn, A.; Oppenheimer, J.; Perry, T.T.; et al. Food allergy: A practice parameter update-2014. J. Allergy Clin. Immunol. 2014, 134. [CrossRef]

46. Schouten, B.; van Esch, B.C.; Hofman, G.A.; van den Elsen, L.W.; Willemsen, L.E.; Garssen, J. Acute allergic skin reactions and intestinal contractility changes in mice orally sensitized against casein or whey. Int. Arch. Allergy Immunol. 2008, 147, 125-134. [CrossRef] 
47. Van Esch, B.C.; Schouten, B.; Hofman, G.A.; van Baalen, T.; Nijkamp, F.P.; Knippels, L.M.; Willemsen, L.E.; Garssen, J. Acute allergic skin response as a new tool to evaluate the allergenicity of whey hydrolysates in a mouse model of orally induced cow's milk allergy. Pediatr. Allergy Immunol. 2010, 21, e780-e786. [CrossRef] [PubMed]

48. Van Esch, B.C.; van Bilsen, J.H.; Jeurink, P.V.; Garssen, J.; Penninks, A.H.; Smit, J.J.; Pieters, R.H.; Knippels, L.M. Interlaboratory evaluation of a cow's milk allergy mouse model to assess the allergenicity of hydrolysed cow's milk based infant formulas. Toxicol. Lett. 2013, 220, 95-102. [CrossRef] [PubMed]

(C) 2019 by the authors. Licensee MDPI, Basel, Switzerland. This article is an open access article distributed under the terms and conditions of the Creative Commons Attribution (CC BY) license (http://creativecommons.org/licenses/by/4.0/). 